\title{
NOVEL ASSOCIATIONS BETWEEN BRCA1 VARIANTS C.181 T>G (RS28897672) AND OVARIAN CANCER RISK IN SAUDI FEMALES
}

\author{
NOVE VEZE IZMEĐU VARIJANTE BRCA1 C.181 T>G (RS28897672) I RIZIKA \\ OD KARCINOMA JAJNIKA KOD SAUDIJSKIH ŽENA
}

\author{
Nora Alyahri ${ }^{1}$, Saba Abdi ${ }^{1}$, Wajahatullah Khan ${ }^{2}$, Mohamed Elrobh ${ }^{1}$, Mohammed H. Addar ${ }^{3}$, \\ Zeneb A. Babay ${ }^{3}$, Mohamed Alanazi ${ }^{1}$, Sooad Aldaihan ${ }^{1}$, Jilani Shaik ${ }^{4}$, Maha Arafah ${ }^{5}$, \\ Narasimha Reddy Parine ${ }^{4}$, Arjumand Warsy ${ }^{6}$ \\ ${ }^{1}$ Department of Biochemistry, College of Science, King Saud University, Riyadh, Saudi Arabia \\ ${ }^{2}$ Department of Basic Sciences, College of Science and Health Professions, King Saud Bin Abdul Aziz \\ University for Health Sciences, Riyadh, Saudi Arabia \\ ${ }^{3}$ Department of Obs/Gyn, College of Medicine, King Saud University, Riyadh, Saudi Arabia \\ ${ }^{4}$ Genome Research Chair, Department of Biochemistry, College of Science, King Saud University, \\ Riyadh, Saudi Arabia \\ ${ }^{5}$ Department of Pathology, College of Medicine, King Saud University, Riyadh, Saudi Arabia \\ ${ }^{6}$ Central Laboratory, Center for Science and Medical Studies for Girls, King Saud University, Riyadh, Saudi Arabia
}

\section{Summary}

Background: Mutations in BRCA1 gene have been implicated in ovarian cancers, and BRCA testing may be conducted in high-risk women. This study was designed to determine the frequency of three single nucleotide polymorphisms (SNPs) variants in BRCA1 gene and BRCA1 expression in Saudi females with ovarian cancer.

Methods: Expression levels of mRNA of BRCA1 gene were studied in 10 ovarian cancer and 10 normal ovarian tissues, by quantitative real time polymerase chain reaction ( $q P C R$ ). The study also included 28 females who had suffered from ovarian cancer and had been successfully operated upon and 90 healthy females with no history of cancer. Blood was drawn in EDTA tubes and used for extraction of DNA. The genotyping was carried out using Taqman ${ }^{\circledR}$ SNP Genotyping kit by RT-PCR. The variants investigated included c.871 T $>C$ (rs799917), c.1040 G>A (rs4986852), c.181 T>G (rs28897672) in BRCA1 gene.

Results: The c.181 T>G (rs28897672) showed significantly different genotype and allele frequencies between the patients and the control subjects ( $p$ value $=0.002$ and 0.02 ,

\section{Kratak sadržaj}

Uvod: Mutacije u genu BRCA1 dovedene su u vezu s karcinomom jajnika i kod žena sa visokim rizikom može se vršiti testiranje BRCA. Ova studija osmišljena je s namerom da se odredi učestalost tri varijante polimorfizama pojedinačnih nukleotida (SNP) u genu BRCA1 i ekspresija BRCA1 kod Saudijki sa karcinomom jajnika.

Metode: Nivoi ekspresije mRNK gena BRCA1 proučavani su u 10 uzoraka tkiva s karcinomom jajnika i 10 zdravih tkiva jajnika pomoću kvantitativne reakcije lanca polimeraze u realnom vremenu (qPCR). Ova studija je takođe obuhvatila 28 žena koje su imale karcinom jajnika i bile uspešno operisane i 90 zdravih žena bez istorije karcinoma. Uzorci krvi uzeti su u EDTA epruvete i korišćeni za ekstrahovanje DNK. Genotipizacija je izvršena pomoću seta Taqman ${ }^{\circledR}$ SNP Genotyping putem RT-PCR. Varijante uključene $u$ istragu bile su c.871 T>C (rs799917), c.1040 G>A (rs4986852), c.181 T>G (rs28897672) u genu BRCA1.

Rezultati: Varijanta c.181 T>G (rs28897672) pokazala je značajno različite učestalosti genotipova alela između pacijenata i kontrolnih subjekata ( $p=0,002$, odnosno 0,02 ).

\footnotetext{
Address for correspondence:

Professor Arjumand Warsy

Senior Scientist, Central Laboratory,

Centre for Science and Medical Studies for Girls,

King Saud University, Riyadh, Saudi Arabia

e-mail: aswarsy@ksu.edu.sa
} 
respectively). The genotype TG was significantly protective $(\mathrm{OR}=0.36, \mathrm{p}$ value $=0.024)$. The mRNA expression of BRCA1 gene was found to be low in the ovarian cancer tissues.

Conclusions: This study showed that c.181 T>G in BRCA1 genes is associated with the development of ovarian cancer in Saudis. More studies are needed to unveil other SNPs that may be associated with ovarian cancer and to understand the mechanism(s) involved in reducing the expression of BRCA1 gene in ovarian cancer tissues.

Keywords: ovarian cancer, BRCA1, polymorphism, Saudi Arabia, c.181 T>G

\section{Introduction}

Ovarian cancer is the sixth most common type of cancer in women (1), and is one of the most lethal malignancies in the world (2), often described as a silent killer (3). The lifetime prevalence of ovarian cancer in the developed countries is about $1-2 \%$. The factors associated with the increased risk of ovarian cancer are advancing age, obesity, nulliparity, use of talcum powder, oestrogen and hormone therapy (2). The most important factor in the development of ovarian cancer is a family history of ovarian or breast cancer, although an identifiable genetic predisposition (germline BRCA1/BRCA2 mutation) is found only in $10-15 \%$ of the patients $(4,5)$. The risk of epithelial ovarian cancer in women with the BRCA1 mutation is $39-46 \%$ while with the BRCA2 mutation it is about $12-20 \%(6)$. Some variants of the BRCA1 gene have been identified, and P871L (rs799917) is one of the most common variants with a minor allele (T) frequency of $32 \%$ among Caucasian cancer patients (7). The BRCA proteins have a nuclear localization, and are expressed in different tissues including breast and ovary. The protein product of BRCA1 is multifunctional and is involved in mechanisms such as DNA repair, transcription, regulation of cell cycle, protein ubiquitination and chromatin remodeling (8).

The Age Standardized Rate (ASR) of the incidence of ovarian cancer in the world in 2012 was 6.1 per 100,000 and the mortality rate was 3.6 per 100,000 (9). In Saudi Arabia during 2012, 307 ovarian cancer cases were reported, accounting for $3.3 \%$ of all newly diagnosed cases, and 190 deaths were reported, accounting for $4.5 \%$ of all cancer deaths. The Age Standardized Rate (ASR) was 2.7 per 100,000 (10).

No information is available on the role of variants of BRCA1 gene in ovarian cancer in females living in Saudi Arabia. This study was designed to examine BRCA1 gene expression levels among ovarian cancer and normal tissues, as well as to determine the role of three BRCA1 gene variants (c.871 T>C, c. $1040 \mathrm{G}>\mathrm{A}$ and c.181 T>G) in the development of ovarian cancer in females living in Saudi Arabia.

Factors that prompted our interest in the study of c.871 T>C (rs799917) polymorphisms in the
Genotip TG imao je značajnu protektivnu ulogu $(\mathrm{OR}=0,36$, $\mathrm{p}=0,024)$. Pokazalo se da je ekspresija mRNK gena BRCA1 bila niska u tkivima s karcinomom jajnika.

Zaključak: Ova studija je pokazala da je c.181 T>G u genima BRCA1 povezan s razvojem karcinoma jajnika kod saudijskih žena. Potrebne su nove studije kako bi se otkrilo koji bi još polimorfizmi (SNP) mogli biti povezani s karcinomom jajnika i kako bi se razumeli mehanizmi uključeni u smanjenje ekspresije gena BRCA1 u tkivima s karcinomom jajnika.

Ključne reči: karcinom jajnika, BRCA1, polimorfizam, Saudijska Arabija, c.181 T>G

$B R C A 1$ gene in ovarian cancer were that it is one of the most studied SNPs, though the results have been inconsistent in different populations, and little is known about the biological, functional, and clinical impact of this polymorphism. Since it is a missense, non-synonymous mutation (P871L) and was reported to be associated with breast cancer, we hypothesized that if found to be associated with ovarian cancer, it could act as a biomarker reliably detected in a minimally invasive blood sample. Selection of c. 1040 $\mathrm{G}>\mathrm{A}$ ( $\mathrm{rs}$ 4986852) in BRCA1 was based on the fact that it is a missense, non-synonymous mutation which replaces Ser at position 1040 by a neutral amino acid Asn and has been associated with breast cancer. We hypothesized that it could potentially alter the function or the stability of the BRCA1 protein, and may play a role in ovarian cancer development. Finally, c.181 T>G (rs28897672) in the BRCA1 gene was selected as it occurs in a highly conserved region, where the $T>G$ transition replaces cysteine with glycine at codon 61 of the BRCA1 protein. This results in a large physicochemical difference due to the difference between cysteine and glycine. Furthermore, this variant was reported to be a common cause of ovarian cancer in individuals of Eastern European ancestry.

\section{Materials and Methods}

\section{Sample collection}

The study was approved by the Ethical Committee at King Khalid Hospital, King Saud University, Riyadh. Each participant was required to give a written informed consent. The clinical data recorded included the age of each subject, family history, clinical profile, and disease severity and recurrence risk.

For gene expression studies, a total of 20 ovarian tissue samples were received from the oncology department of King Khalid University hospital (KKUH), King Saud University (KSU), Riyadh, Saudi Arabia. Ten of these samples were ovarian cancer tissues collected at the time of surgical removal of the affected ovaries. Histological biopsies were cut into 
small sections (1-2 $\mathrm{mm}$ ) and were subjected to routine histological examination procedures. The sample was considered to be cancerous only when the biopsy showed more than $80 \%$ malignant cells. Five tissues were adjacent to the normal ovarian tissues, and another five were obtained from patients who underwent surgery for benign ovarian tumor (ovarian cyst). These ten samples were used as controls. All tissue samples were kept in RNAlater solution (Ambion ${ }^{\circledR}$ Life Technologies, USA) to avoid degradation of RNA and stored at $-80{ }^{\circ} \mathrm{C}$ until used for analysis.

For genotyping, blood samples were collected in EDTA tubes (BD Vacutainer, USA) by venepuncture, from 28 ovarian cancer patients (these patients had already undergone surgical procedure, and their fresh tissues were not available for gene expression studies), and 92 normal individuals, who were attending the clinic for routine investigations and had no history of ovarian or any other cancer.

\section{Extraction of RNA and DNA}

The RNA was extracted from ovarian tissue samples. For RNA extraction, the tissue was homogenized using Medic tools (Switzerland) homogenizer. RNA was extracted using the AllPrep DNA/RNA Mini kit according to the manufacturer's protocol (Qiagen, Germany). Whole blood was used for the extraction of DNA, using QIAamp DNA Blood Mini Kit.

\section{cDNA Preparation}

Extracted RNA (approximately $1 \mu \mathrm{g}$ ) from each sample was used as a template for the reverse transcription reaction. Single stranded cDNA was synthesized from the purified RNA using random primers and the high-capacity cDNA reverse transcription kit, according to the protocol provided by the manufacturer (Applied Biosystems, USA).

The cDNA Reverse Transcription (RT) reactions were prepared by pipetting 2 X RT master mixes (10 $\mu \mathrm{L}$ ) into each well of a 96-well reaction plate and adding the same amount of RNA samples. The plate was placed in the thermal cycler for which the Reverse Transcription protocol had been set as: $25^{\circ} \mathrm{C}$ for 10 $\min , 37^{\circ} \mathrm{C}$ for $120 \mathrm{~min}, 85^{\circ} \mathrm{C}$ for $5 \mathrm{~min}$ and $4{ }^{\circ} \mathrm{C}$ for $5 \mathrm{~min}$

\section{Expression Primer Screening}

The primers were selected from already published reports. The expression primers for BRCA1-C were F-5'-CATCATTCACCCTTGGCACA-3' and R-3'CATTGTCCTCTGTCCAGGCAT-5'. Glyceraldehyde 3phosphate dehydrogenase (GAPDH) was used as the internal reference gene, and the primers used were: F- 5'-TGATGACATCAAGAAGGTGGTGAA-3' and R-
3'-TCCTTGGAGGCCATGTGGGCCAT-5'. Quantitative real-time PCR analysis was carried out using SYBR Green (Bio-Rad Laboratories) according to the manufacturer's instructions. The $25 \mu \mathrm{L}$ PCR reaction contained $6 \mu \mathrm{L}$ of template cDNA $(20 \mathrm{ng} / \mu \mathrm{L})$ with $1 \mu \mathrm{L}$ of each primer set $(100 \mathrm{ng} / \mu \mathrm{L}), 12.5 \mu \mathrm{L}$ SYBER Green master mixed $4.5 \mu \mathrm{L}$ of DNase, RNase free water. The conditions used for PCR amplification were as follows: initial denaturation at $95{ }^{\circ} \mathrm{C}$ for 5 min, followed by 40 cycles of $95^{\circ} \mathrm{C}$ for $20 \mathrm{~s}, 55^{\circ} \mathrm{C}$ for $30 \mathrm{~s}$ and $72{ }^{\circ} \mathrm{C}$ for $30 \mathrm{~s}$.

The relative expression levels of $B R C A 1 \mathrm{mRNA}$ were quantified using the standard curve method. A GAPDH transcript was used for relative quantification and to normalize the amplification signal of the target in all the experimental samples. The target and reference genes were amplified under the same experimental conditions, run separately in triplex real-time PCR with the same concentration of cDNA per reaction. Cycle threshold $\mathrm{Ct}$ (defined as the cycle number at which the fluorescence exceeds a threshold level) values were determined for each reaction (run in triplicates) using a sequence detection software. Data were analyzed and relatively compared using the comparative $\mathrm{Ct}$ method [2 $\mathrm{Ct}$ (Livak) relative expression method] that determines the ratio between the amount of target and an endogenous reference gene.

The fold changes between disease and control samples for each gene were compared, and the data analyses were performed with normalized real-time PCR data.

\section{Genotyping using TaqMan assay}

Three variants (c.871 T>C, c.1040 G>A, c.181 T>G) in the BRCA1 gene were investigated using TaqMan genotype assay according to the manufacturer's instructions (Applied Biosystems, USA).

\section{Statistical analysis}

Frequencies of the genotypes and alleles of each SNP were calculated, and independent sample t-test was used to compare the results in the control and patient groups. Hardy Weinberg $(\mathrm{H}-\mathrm{W})$ equilibrium tests for association (http://ihg.gsf.de/cgi-bin/hw/ hwa1.pl) were applied to test if the $\mathrm{H}-\mathrm{W}$ equilibrium was obeyed. Odds ratios (OR), 95\% confidence intervals (Cls) and $\mathrm{p}$-value were determined by logistic regression to examine the association between each genotype and risk of ovarian cancer. The common allele and genotype were used as the reference. Significance was set at $p<0.05$. The obtained results from this study were compared with the results reported from other populations using specific statistical tests. The gene expression results in the cancer tissue were compared with the results in the normal tissue using Student's' $t^{\prime}$ test. 


\section{Results}

\section{Clinical characteristics}

Table I summarizes the clinical data of women from whom the ovarian tissue samples were extracted, and Table II presents the clinical data of the women from whom the blood samples were obtained. These tables also show the clinical profile, including family history, disease severity, recurrence risk and age at first diagnosis.

\section{Tissue identification and histopathology}

To confirm the diagnosis of ovarian cancer and to distinguish the cancer tissue from normal tissue,

Table I Characteristics of women from whom ovarian tissue samples were extracted.

\begin{tabular}{|c|c|}
\hline Age (years) & Number (\%) \\
\hline$<50$ & $5(50 \%)$ \\
\hline $50-59$ & $3(30 \%)$ \\
\hline 60 & $2(20 \%)$ \\
\hline Family History & \\
\hline 0 & Yes \\
\hline 10 (100\%) & No \\
\hline Disease Severity & 0 \\
\hline Stage I & $1(10 \%)$ \\
\hline II & 0 \\
\hline III & $9(90 \%)$ \\
\hline IV & \\
\hline &
\end{tabular}

histopathological examination was carried out. The histological characteristics of the biopsy sections were recorded and stained with hematoxylin and eosin and examined under the microscope to distinguish between ovarian cancer and the adjacent normal ovarian biopsies. Figure 1 presents the histological differences between the normal and cancerous ovarian tissues.

Table II Characteristics of ovarian cancer patients from whom blood samples were obtained $(\mathrm{N}=28)$ and the controls $(\mathrm{N}=98)$.

\begin{tabular}{|c|c|c|}
\hline Age (years) & Number of Patients & Normal Controls \\
\hline$<50$ & $15(53.6 \%)$ & $44(47.8 \%)$ \\
\hline $50-59$ & $10(35.7 \%)$ & 34 (36.9\%) \\
\hline 60 & $3(10.7 \%)$ & $13(14.1 \%)$ \\
\hline No information & 0 & $1(1.1 \%)$ \\
\hline \multicolumn{2}{|l|}{ Family History } & \\
\hline Yes & $13(46.4)$ & \\
\hline No & $15(53.6)$ & \\
\hline No information & 0 & \\
\hline \multicolumn{2}{|l|}{ Disease Severity } & \\
\hline Stage I & $15(53.6)$ & \\
\hline II & 0 & \\
\hline III & $2(7.1)$ & \\
\hline IV & $6(21.4)$ & \\
\hline No information & $5(17.9)$ & \\
\hline
\end{tabular}

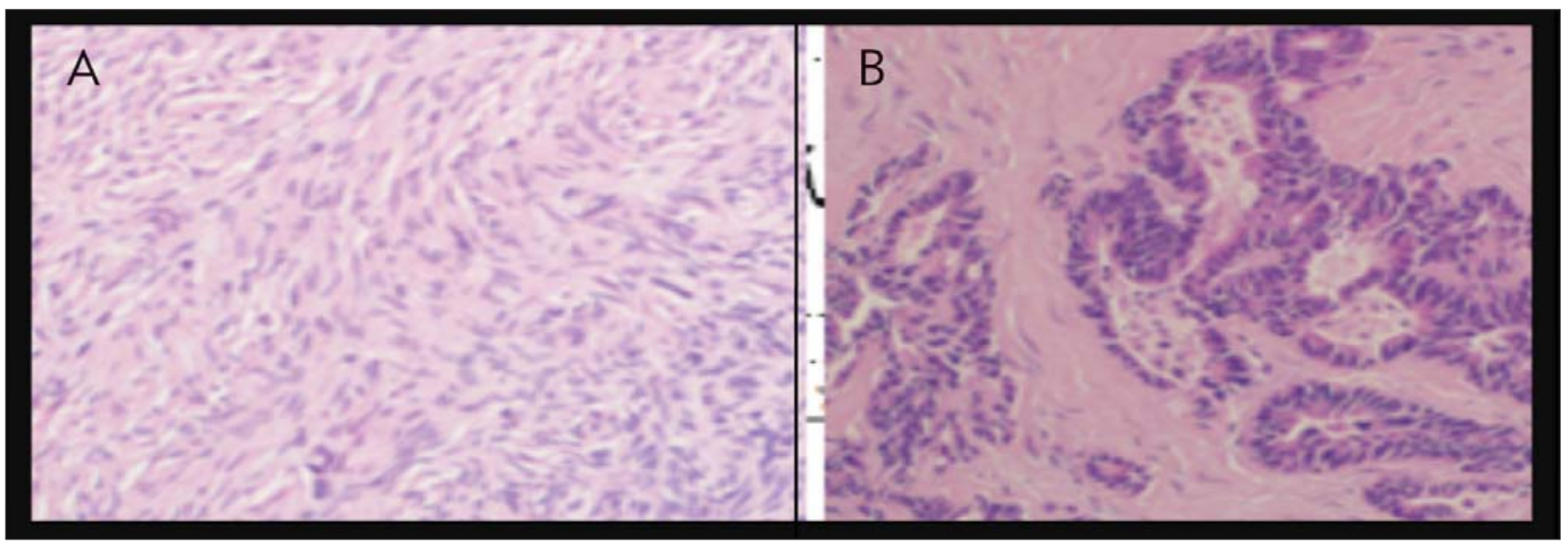

Figure 1 Tissue identification and histopathology. (A) Normal ovarian tissue stained by Hematoxylin and eosin stain (H \& E) and visualized under a microscope with a digital zoom (micro, 200X). (B) Ovarian serous cyst adenocarcinoma tissue stained by (H\&E) and visualized under a microscope with a digital zoom (micro, 200X); malignant cells are showing large and pleomorphic nuclei with areas of invasion and necrosis. 
Genotype and allele frequencies of SNPs in BRCA1 gene in ovarian cancer patients and controls

The genotypes were counted, and genotype and allele frequencies were obtained. The genotype and allele frequencies of all three studied SNPs are presented in Table III. Of the three studied variants, BRCA1 c.871 T>C, c. $181 \mathrm{~T}>\mathrm{G}$ were polymorphic in Saudis, but c.1040 G>A was not polymorphic, and the minor ' $A$ ' allele was not encountered in the patients or controls. BRCA1 c.871 T>C occurred at the same frequency in the patients and controls and showed no association with ovarian cancer. BRCA1 c.181 T>G correlated significantly, where for BRCA1 c.181 $\mathrm{T}>\mathrm{G}$, the mutant $\mathrm{G}$ allele showed a protective effect (i.e. for TG: $\mathrm{OR}=0.360 ; 95 \% \mathrm{Cl}=0.146-$ 0.889; $\mathrm{p}=0.024)$.

\section{Gene expression quantification}

Gene expression of BRCA1 was studied in ten ovarian cancer tissues and ten normal tissues. Figure 2 presents the expression of BRCA1 gene in cancerous

Table III Genotype and allele frequency of the studied SNPs in ovarian cancer patients compared to control group.

\begin{tabular}{|c|c|c|c|c|c|c|}
\hline & \multirow{2}{*}{$\begin{array}{l}\text { Cancer } \\
\text { No. (\%) }\end{array}$} & \multirow{2}{*}{$\begin{array}{l}\text { Control } \\
\text { No. (\%) }\end{array}$} & \multicolumn{3}{|c|}{ Ovarian cancer vs. Control } & \multirow{2}{*}{ P- Value } \\
\hline & & & OR & $95 \% \mathrm{Cl}$ & $\chi^{2}$ & \\
\hline \multicolumn{7}{|c|}{ rs799917 T>C Genotype Frequency } \\
\hline TT & $28(100)$ & $90(97.8)$ & Ref & & & \\
\hline TC & 0 & $1(1.1)$ & 1.058 & $0.042-26.70$ & 0.31 & 0.577 \\
\hline CC & 0 & $1(1.1)$ & 1.058 & $0.042-26.709$ & 0.31 & 0.577 \\
\hline $\mathrm{CT}+\mathrm{CC}$ & 0 & 2 & 0.635 & $0.030-13.61$ & 0.62 & 0.431 \\
\hline \multicolumn{7}{|c|}{ Alleles Frequency } \\
\hline $\mathrm{T}$ & $56(100)$ & $181(98.4)$ & 2.179 & $0.111-42.82$ & 0.92 & 0.761 \\
\hline C & 0 & $3(1.6)$ & 0.459 & $0.023-9.019$ & 0.92 & 0.761 \\
\hline \multicolumn{7}{|c|}{ rs4986852 G>A } \\
\hline \multicolumn{7}{|c|}{ Genotype Frequency } \\
\hline GG & $28(100)$ & $92(100)$ & Ref & & & \\
\hline AG & 0 & 0 & 3.246 & $0.063-167.278$ & & 1.000 \\
\hline AA & 0 & 0 & 3.246 & $0.063-167.2$ & & 1.000 \\
\hline$A G+A A$ & 0 & 0 & 3.246 & $0.063-167.2$ & & 1.000 \\
\hline \multicolumn{7}{|c|}{ Alleles Frequency } \\
\hline G & $56(100)$ & $184(100)$ & 0.306 & $0.006-15.609$ & & 1.000 \\
\hline A & 0 & 0 & 3.265 & $0.064-166.442$ & & 1.000 \\
\hline \multicolumn{7}{|c|}{ rs28897672 T>G } \\
\hline \multicolumn{7}{|c|}{ Genotype Frequency } \\
\hline TT & $15(57.7)$ & $27(32.5)$ & Ref & & & \\
\hline TG & $11(42.3)$ & $55(66.3)$ & 0.360 & $0.146-0.889$ & 5.09 & 0.024 \\
\hline GG & 0 & $1(1.2)$ & 0.591 & $0.023-15.4$ & 0.55 & 0.459 \\
\hline $\mathrm{TG}+\mathrm{GG}$ & 11 & 56 & 0.354 & $0.143-0.87$ & 5.29 & 0.021 \\
\hline \multicolumn{7}{|c|}{ Alleles Frequency } \\
\hline $\mathrm{T}$ & $41(80)$ & $109(70)$ & 1.949 & $0.931-4.080$ & 3.21 & 0.073 \\
\hline G & $11(20)$ & $57(30)$ & 0.513 & $0.245-1.074$ & 3.21 & 0.073 \\
\hline
\end{tabular}




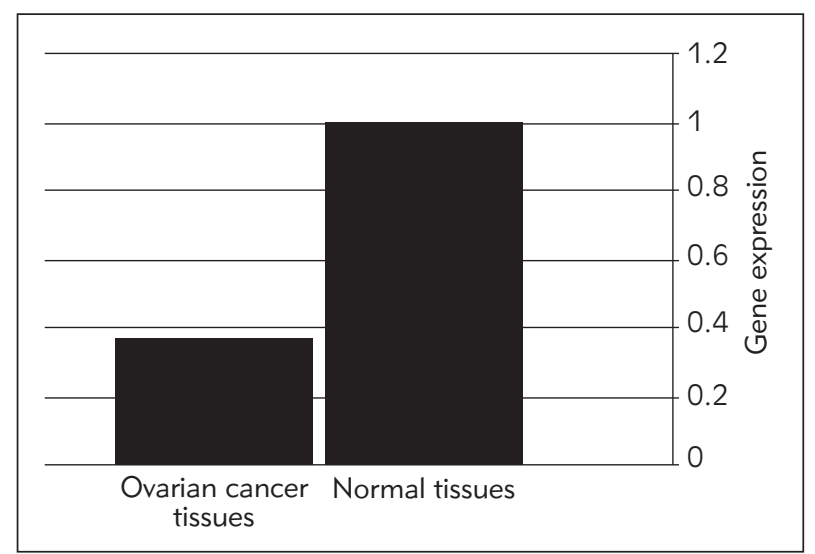

Figure 2 The gene expression of BRCA1 in ovarian cancer tissue and normal tissue. The mean \pm SD of normal tissues $=$ $1 \pm 0.005$ and the mean of ovarian cancer tissues $=0.3719$ $\pm 0.137 ; \mathrm{p}$ value $<0.0001$

and normal tissues. The gene expression was lower in the cancerous tissue compared to the normal tissue, and the difference was statistically significant $(p<0.0001)$.

\section{Discussion}

Ovarian cancer is common in women and is considered as one of the most lethal malignancies. Since it is associated with non-specific symptoms, it is usually diagnosed at a late stage, and by then the disease has spread to such an extent that survival frequency is reduced, and hence ovarian cancer has gained the reputation of a silent killer (3). Early diagnosis followed by early intervention has been shown to significantly reduce the mortality associated with ovarian cancer. If such genetic markers are identified that are significantly associated with ovarian cancer, either in their expression or the associated alleles, then a closer follow-up of genetically susceptible women can play an important role in early diagnosis and, hence, will help in early intervention. It is with the aim to identify such variants in the BRCA1 gene that this study was conducted.

During this study, the collection of samples was a limiting step, since ovarian cancer is reported to occur at a frequency of 2.7/100000 (10). During our study period, only ten women were diagnosed who were undergoing surgical removal of the affected ovaries. Of these, 9 of the women were at stage IV and $8 / 10$ women were diagnosed at age $<60$ years. The adjacent normal tissue could not be obtained for 5 of these women since the entire ovaries were already affected. Hence, five normal control tissues were obtained from females who were undergoing surgical removal of ovaries for pathologies other than ovarian cancer. Results of gene expression in both groups were the same and showed significantly higher gene expression of BRCA1, both in the normal tissue adjacent to the affected ovaries and in the normal ovaries from unmatched women, compared to the ovarian cancer tissue, indicating clearly that BRCA1 gene expression is reduced in cancer tissues.

The selection of BRCA1 was based on the fact that mutations in the BRCA1 tumor suppressor gene are associated with susceptibility to both hereditary breast and ovarian cancer (11). It suppresses the development of cancer, and its reduced expression could be associated with the risk of cancer development. Approximately $5 \%$ to $15 \%$ of ovarian cancers are inherited. Germline mutations in the BRCA1 gene have been shown to account for $90 \%$ of ovarian cancer, conferring a 54\% cumulative lifetime risk compared to $1.8 \%$ of the general population (12). Although somatic mutations in BRCA1 are uncommon in sporadic ovarian tumors (13), more than $72 \%$ of high-grade sporadic ovarian cancers have shown down-regulation of BRCA1, suggesting that BRCA1 may also be involved in the development of sporadic epithelial ovarian cancer (15). Epigenetic inactivation of BRCA1 is at least partially due to hyper-methylation of the BRCA1 promoter, which has been observed in up to $15 \%$ of the cases (14). Wang et al. (15) have reported a decreased expression of BRCA 1 in $16 \%$ of benign tumors, $38 \%$ of borderline tumors, and $72 \%$ of carcinomas. These results suggest that the downregulation of BRCA1 protein may play a role in the development of ovarian cancers (15).

In our study, many possible explanations can be given for the reduced mRNA expression of the BRCA1 gene. This reduced expression may be a result of an epigenetic event, such as hyper-methylation of the BRCA1 promoter, which would reduce the mRNA level by decreasing transcription of the gene, and which will be associated with amelioration in the protein level. Such a possibility can be confirmed by immunohistochemistry (IHC) techniques. Other studies have shown loss of BRCA 1 protein expression, and it is suggested that such loss of expression is more common in ovarian cancer than in breast cancer (16).

Other causes of decreased expression of the BRCA1 gene could be due to certain mutations. Several studies have shown that mutations in the BRCA1 tumor suppressor gene are associated with a significant risk of breast and ovarian cancer development (17), yet over $90 \%$ of ovarian cancer is believed to arise sporadically. BRCA1 mutations are uncommon in sporadic ovarian cancer. However, BRCA1 dysfunction has frequently been observed $(18,19)$. Gene deletion (loss of heterozygosity) or misregulation of related genes in the BRCA1 pathway, leading to silencing of BRCA1 through decreased expression may be important in the pathogenesis of a significant proportion of sporadic tumors $(20,21)$. Recent clinical data suggests that tumor expression of BRCA1 has predictive value in patients without a BRCA1 mutation (19, $22)$. A correlative study on BRCA1 protein expression in 230 ovarian tumors, with survival data on 152 patients, suggests a role for BRCA1 in the progression 
of sporadic ovarian carcinoma (19). The frequency of $B R C A 1$ and BRCA2 mutations has been reported in several studies in breast and ovarian cancer patients. A study on Moroccan women with hereditary breast and ovarian cancer showed the frequency to be $25.64 \%$. Other studies conducted in neighboring populations such as Tunisia and Algeria have reported frequencies of $19.4 \%$ and $11.4 \%(23)$, respectively.

During this study, we investigated three variants in the BRCA 1 gene to examine a possible association with ovarian cancer and compared the results reported in studies of other populations. We identified that the variant BRCA1 c.871 T>C, which resulted in a P871L substitution in the BRCA1 protein, was one of the most studied SNPs, though the results have been found to be inconsistent in different populations. Previous studies have examined the association between the P871L polymorphism in BRCA1 gene and the risk of developing ovarian cancer. A gynaecologic oncology group study found that patients with the CT or TT vs. the CC genotype in BRCA1 (P871L) show a modestly increased risk of ovarian cancer and disease recurrence (24). The P871L polymorphisms were associated with an increased risk of developing ovarian cancer, however, such a correlation was not confirmed in a large-scale study (25). In another investigation, the North Carolina ovarian cancer study group showed that BRCA1 $\mathrm{P} 871 \mathrm{~L}$ polymorphism was not associated with ovarian cancer risk $(\mathrm{OR}=0.9$, $95 \% \mathrm{Cl}=0.6-1.9)$. The results of our study are in agreement with the results of the North Carolina study and show that there was no significant difference in the frequency of the three genotypes of $B R C A 1$ variant $\mathrm{c} .871 \mathrm{~T}>\mathrm{C}$ in ovarian cancer and normal controls.
Interestingly, BRCA1 c.871 T>C has also been studied in other cancers, and an increased association has been reported with oesophageal squamous cell carcinoma (26), cervical cancer (27), gastric cancer (29), non-Hodgkin's lymphoma (29) and glioblastoma (31). Some studies have also shown an association with breast cancer $(31,32)$, but several others failed to show any association with breast cancer, chronic myeloid leukemia and ovarian cancer (33-35). A large meta-analysis involving 19878 patients failed to reveal any association with breast cancer (36). Earlier reports on breast cancer in Saudi and Omani populations also failed to reveal any such association $(37,38)$.

The SNP variant BRCA1 c. $1040 \mathrm{G}>\mathrm{A}$ in the $B R C A 1$ gene was recently studied in a Polish population and was shown to have an association with breast cancer (32). In the present study, we did not observe any GA or AA genotypes and the A allele was absent, suggesting that this SNP variant is not polymorphic in the Saudis. No other reports of association of this SNP to any cancer were found in the literature, and no association was seen with ovarian cancer.

A novel finding in this study was the finding of an association between variant BRCA1 c.181 T>G and ovarian cancer, where the minor allele showed a protective effect against ovarian cancer development $(O R=0.513)$. This missense mutation located in exon 5 results in the substitution of cysteine by glycine at position 61 and occurs in a highly conserved cysteine ligating residue in the ring finger domain of BRCA 1 . It has previously been reported as a founder mutation among Central European populations (40). In Polish families with breast-ovarian cancer, it accounted for $20 \%$ of identified mutations (41). It was also observed

Table IV Comparison of frequency of rs799917 T>C and rs4986852 G>A in BRCA1 in Saudis with different populations.

\begin{tabular}{|c|c|c|c|c|c|c|}
\hline Populations & No. of samples $(n)$ & \multicolumn{3}{|c|}{ Genotype frequency (\%) } & \multicolumn{2}{|c|}{ Allele frequency (\%) } \\
\hline \multicolumn{7}{|l|}{ rs799917 T>C } \\
\hline & & TT & CT & $\mathrm{CC}$ & $\mathrm{T}$ & $\mathrm{CC}$ \\
\hline European & 226 & 10.6 & 46 & 43.4 & 33.6 & 66.4 \\
\hline Asian & 172 & 7 & 40.7 & 52.3 & 27.3 & 72.7 \\
\hline Sub-Saharan African & 226 & 85.8 & 14.2 & & 92.9 & 7.1 \\
\hline African American & 124 & 69.4 & 25.8 & 4.8 & 82.3 & 17.7 \\
\hline Saudis (this study) & 92 & 97.8 & 1.1 & 1.1 & 98.3 & 1.6 \\
\hline \multicolumn{7}{|l|}{ rs4986852 G>A } \\
\hline & & GG & GA & $\mathrm{AA}$ & G & $A$ \\
\hline Asian & 164 & 96.3 & 3.7 & 0 & 98.2 & 1.8 \\
\hline European & 226 & 88.5 & 11.5 & 0 & 94.2 & 5.8 \\
\hline Sub-Saharan African & 222 & 99.1 & 0.9 & 0 & 99.5 & 0.5 \\
\hline Saudi control & 92 & 100 & 0 & 0 & 100 & 0 \\
\hline
\end{tabular}


in a study from Morocco (42). The presence of this mutation in Morocco and Algeria suggests that this mutation represents a mutational hotspot, but only the haplotype analysis can establish whether such an association exists or not in the families who had a common ancestor (42). An extensive search of the literature did not reveal any studies on any other cancer patient groups. Further studies on a larger sample size may show associations with cancer.

For two variants (BRCA1 c.871 T>C and BRCA1 c.181 $T>G$ ) for which data was available on $\mathrm{NCBI}$, we compared the frequencies of the genotypes and allele in the normal Saudi population with those reported for other populations. The comparative results are summarized in Table IV. For the variant BRCA1 c.871 T>C, the results show that the homozygous genotype TT is more frequent in SubSaharan African and African American populations compared to the other genotypes (CT and CC). The results obtained during our study showed that Saudi results were similar to the results in Sub-Saharan Africans, but differed significantly from the results reported in Asians and Europeans. Finally, the variant BRCA1 c.181 T>G was polymorphic in the Asians and Europeans, but like in Saudis, it was not polymorphic amongst Sub-Saharan Africans (Table IV). This comparison shows the significant heterogeneity that exists between populations, making it necessary to investigate SNP frequencies in each population and to study their association with different disease states.

\section{References}

1. Garcia M, Jemal A, Ward EM, et al. Global cancer facts and figures 2007. Atlanta: American Cancer Society, 2007

2. Bohra U. Recent advances in management of epithelial ovarian cancer. Apollo Medicine 2012: 9: 212-18.

3. Lippi G, Chiozza L, Mattiuzzi C, Plebani M. Patient and sample identification. Out of the maze? J Med Biochem 2017; 36: 107-12

4. Risch HA, McLaughlin JR, Cole DE, et al. Population BRCA1 and BRCA2 mutation frequencies and cancer penetrances: a kin-cohort study in Ontario, Canada. J Natl Cancer Inst 2006; 98: 1694-706.

5. Chen $S$, Iversen ES, Friebel $T$, et al. Characterization of BRCA1 and BRCA2 mutations in a large United States sample. J Clin Oncol 2006; 24: 863-71.

6. Hennessy BT, Coleman RL and Markman M: Ovarian cancer. Lancet 2009; 374: 1371-82.

7. Packer BP, Yeager M, Burdett L, Welch R, Beerman M, Qi $L$, et al. SNP 500 cancer. A public resource for sequence validation, assay development, and frequency analysis for genetic variation in candidate genes. Nucleic Acids Res (2006) 34: D617-21.doi: 10.1093/nar/ gkj151 (Database issue).

8. Carter RF. BRCA1, BRCA2 and breast cancer: a concise clinical review. Clin Invest Med 2001; 24: 147-57.

\section{Conclusion}

The results of this study showed a reduced level of expression of BRCA1 gene in the ovarian cancer samples compared to normal ovarian tissue samples. The BRCA1 SNPs variant BRCA1 c. $181 \mathrm{~T}>\mathrm{G}$ was significantly associated with development of ovarian cancer in Saudi females. However, SNPs variants BRCA1 c.871 T>C and BRCA1 c.1040 G>A did not show any association with ovarian cancer and the SNP variant BRCA1 c.1040 G>A was not polymorphic in this population. Our study suggests that some variants in BRCA1 genes may be associated with the development of ovarian cancer in Saudi females. Further studies are needed to explore other variants that may be associated with ovarian cancer and the mechanism(s) involved in the reduced expression of BRCA1 gene in ovarian cancer tissues.

Acknowledgements. The project was financially supported by King Saud University through the Vice Deanship of Research Chairs.

\section{Conflict of interest statement}

The authors stated that they have no conflicts of interest regarding the publication of this article.

9. Ferlay J, Soerjomataram I, Ervik $M$, et al. GLOBOCAN 2012 v1.0, cancer incidence and mortality worldwide: IARC CancerBase 2013 No. 11. Lyon: IARC.

10. Cancer Incidence and Survival Report Saudi Arabia, 2007.

11. Cannistra SA. Cancer of the ovary. N Engl J Med 2004; 351: 2519-29.

12. Pal T, Permuth-Wey J, Betts JA, et al. BRCA1 and BRCA2 mutations account for a large proportion of ovarian carcinoma cases. Cancer 2005; 104: 2807-16.

13. McCoy ML, Mueller CR, Roskelley CD. The role of the breast cancer susceptibility gene 1 (BRCA1) in sporadic epithelial ovarian cancer. Reprod Biol Endocrinol 2003; 1: 72

14. Chan KY, Ozcelik H, Cheung AN, Ngan HY, Khoo US Epigenetic factors controlling the BRCA1 and BRCA2 genes in sporadic ovarian cancer. Cancer Res 2002; 62: 4151-6.

15. Wang C, Horiuchi A, Imai T, Ohira S, Itoh $K$, Nikaido T et al. Expression of BRCA1 protein in benign, borderline, and malignant epithelial ovarian neoplasms and its relationship to methylation and allelic loss of the BRCA1 gene. J Pathol 2014; 202: 215-23.

16. Hilton JL, Geisler JP, Rathe JA, et al. Inactivation of BRCA1 and BRCA2 in ovarian cancer. J Natl Cancer Inst 2012; 18: 1396-406. 
17. Matloff ET. The breast surgeon's role in BRCA1 and BRCA2 testing. Am J Surg 2000; 180: 294-8.

18. Hilton JL, Geisler JP, Rathe JA, Hattermann-Zogg MA DeYoung B, Buller RE. Inactivation of BRCA1 and BRCA2 in ovarian cancer. J Natl Canc Inst 2002; 94: 1396-406.

19. Thrall M, Gallion HH, Kryscio R, Kapali M, Armstrong DK, DeLoia JA. BRCA1 expression in a large series of sporadic ovarian carcinomas: a Gynecologic Oncology Group study. Int J Gynecol Cancer 2006; (16 Suppl) 1: 166-71.

20. Turner N, Tutt A, Ashworth A. Hallmarks of 'BRCAness' in sporadic cancers. Nat Rev 2004; 4: 814-19.

21. Weberpals JI, Clark-Knowles KV, Vanderhyden BC. Sporadic epithelial ovarian cancer: clinical relevance of BRCA1 inhibition in the DNA damage and repair pathway. J Clin Oncol 2008; 26: 3259-67.

22. Quinn JE, James CR, Stewart GE, Mulligan JM, White $P$, Chang GK, et al. BRCA1 mRNA expression levels predict for overall survival in ovarian cancer after chemotherapy. Clin Cancer Res 2007; 13: 7413-20.

23. Cherbal F, Bakoura R, Adaneb S, Boualgac K, BenaisPont G, Maillet P. BRCA1 and BRCA2 germline mutations screening in Algerian breast/ovarian cancer families. Dis Markers 2010; 28: 377-84.

24. Tian CQ, Darcy KM, Krivak TC, et al. Assessment of the Prognostic Value of Two Common Variants of BRCA1 and BRCA2 Genes in Ovarian Cancer Patients Treated with Cisplatin and Paclitaxel: A Gynecologic Oncology Group Study. Frontiers in oncology 2013; 3: 00206.

25. Wenham RM, Schildkraut JM, McLean K, Calingaert $B$, et al. Polymorphisms in BRCA1 and BRCA2 and Risk of Epithelial Ovarian Cancer. Clin Cancer Res 2003; 9: 4396-403.

26. Zhang X, Wei J, Zhou L, Zhou C, et al. A functional BRCA1 coding sequence genetic variant contributes to risk of esophageal squamous cell carcinoma. Carcinogenesis 2013; 34(10): 2309-13.

27. Zhou X, Han S, Wang S, et al. Polymorphisms in HPV E6/E7 protein interacted genes and risk of cervical cancer in Chinese women: a case-control analysis. Gynecol Oncol 2009; 114(2): 327-31.

28. Wang K, Xu L, Pan L, Xu K, Li G. The functional BRCA1 rs799917 genetic polymorphism is associated with gastric cancer risk in a Chinese Han population. Tumor Biol 2015; 36(1): 393-7.

29. Chen Y, Zheng T, Lan Q, Kim C, Qin Q, Foss F, et al. Polymorphisms in DNA repair pathway genes, body mass index, and risk of non-Hodgkin lymphoma. Am J Hematol 2013 Jul; 88(7): 606-11. doi: 10.1002/ajh. 23463.

30. Chang JS, Yeh RF, Wiencke JK, Wiemels JL, Smirnov I, Pico AR, Tihan T, et al. Pathway analysis of single-nucleotide polymorphisms potentially associated with glioblastoma multiforme susceptibility using random forests. Cancer
Epidemiol Biomarkers Prev 2008; Jun; 17(6): 1368-73. doi: 10.1158/1055-9965.EPI-07-2830.

31. Huo X, Lu C, Huang X, Hu Z, Jin G, Ma H, Wang X, et al. Polymorphisms in BRCA1, BRCA1-interacting genes and susceptibility of breast cancer in Chinese women. J Cancer Res Clin Oncol 2009 Nov; 135(11): 1569-75. doi: 10.1007/s00432-009-0604-6.

32. Romanowicz H, Strapagiel D, Słomka M, Sobalska-Kwapis M, Kępka E, Siewierska-Górska A, et al. New single nucleotide polymorphisms (SNPs) in homologous recombination repair genes detected by microarray analysis in Polish breast cancer patients. Clin Exp Med 2016; Nov 30.

33. Gutiérrez-Malacatt $H$, Ayala-Sanchez M, Aquino-Ortega X, Dominguez-Rodriguez J, Martinez-Tovar A, OlarteCarrillo I, et al. The rs61764370 Functional Variant in the KRAS Oncogene is Associated with Chronic Myeloid Leukemia Risk in Women. Asian Pac J Cancer Prev 2016; 17(4): 2265-70.

34. Ma J, Liu M, Zhang X, BuRi G. Correlation analysis of sporadic breast cancer and BRCA1 gene polymorphisms in the Han Nationality and the Mongol Nationality of Inner Mongolia Region. Zhonghua Yi Xue Za Zhi 2015 Dec 8; 95(46): 3746-9.

35. Wu HC, Delgado-Cruzata L, Machella N, Wang Q, Santella RM, Terry MB. DNA double-strand break repair genotype and phenotype and breast cancer risk within sisters from the New York site of the Breast Cancer Family Registry (BCFR). Cancer Causes Control 2013 Dec; 24(12): 2157-68. doi: 10.1007/s10552-013-0292-z.

36. Qin TT, Chen T, Zhang Q, et al. Association between BRCA1 rs799917 polymorphism and breast cancer risk: A meta-analysis of 19,878 subjects. Biomed Pharmacother 2014; 68(7): 905-10.

37. Hasan TN, Shafi G, Syed NA, et al. Lack of association of BRCA1 and BRCA2 variants with breast cancer in an ethnic population of Saudi Arabia, an emerging high-risk area. Asian Pac J Cancer Prev 2013; 14(10): 5671-4.

38. Al-Moundhri MS, Al-Ansari A, Al-Mawali K, Al-Bahrani B. BRCA1 gene Molecular Alterations in Omani Breast Cancer Patients. Gulf J Oncolog 2013; 1(14): 45-51.

39. https: //www.ncbi.nlm.nih.gov/projects/SNP/snp_ref. cgi?rs $=878970087(5 / 08 / 2017)$

40. Janavičius R. Founder BRCA1/2 mutations in Europe: implications for hereditary breast-ovarian cancer prevention and control. EPMA J 2010; 1: 397-412.

41. Gorski B, Byrski T, Huzarski T, Jakubowska A, Menkiszak J, Gronwald J, et al. Founder mutations in the BRCA1 gene in Polish families with breast-ovarian cancer. Am J Hum Genet 2000; 66: 1963-8.

42. Tazzite A, Jouhadi $H, N$ adif $S$, et al. BRCA1 and BRCA2 germline mutations in Moroccan breast/ovarian cancer families: Novel mutations and unclassified variants. Gynecologic Oncology 2012; 125: 687-92. 